\title{
INVESTIGATION ON THE PROGNOSIS OF SYPHILIS WITH ESPECIAL REFERENCE TO RECIDIVATION IN THE BRAIN AND MARROW *
}

\section{By JAMES STRANDBERG}

DESPITE all statistics and all that has been written on the prognosis of syphilis our conception of this important question is as yet rather obscure. The causes hereof are manifold, but it is unnecessary to discuss them here. Likewise we need but hint that the pessimists concerning the value of the treatment are usually to be found among internists, neurologists, and psychiatrists, who see the majority of the later fatal recurrences of the disease. The increase of syphilitic vascular and nervous diseases of recent years, be it real or apparent, is a problem which has been illustrated from many quarters in dermatological literature. It has been attempted to prove by statistics that the modern treatment has changed the nature of the disease so that from being principally a skin disease it has now become more of a vascular and nervous disease. The treatment has even been charged with provoking nervous and vascular symptoms. The life insurance companies have produced extensive statistics which plainly point to an excess mortality in syphilitics; no sign that this has been changed for the better during the last decades has been observed. From the Scandinavian countries we have the oft-quoted statistics of Runeberg (I898), Bruhn-Fåhraeus (I902), Tiselius (I904), and Lennmalm (I923) ; Bruusgaard's sensational account of the peculiar, untreated syphilis material from Norway which he published in 1928, will no doubt still be recalled. Boas, and likewise Lindstedt have put forward their views on the significance of syphilis in life insurance, and I have myself in a couple of papers referred to kindred problems and attempted a critical examination of them.

* Reprinted by kind permission of the Author from the proceedings of the Northern Dermatological Society, July Ioth, I935. 


\section{BRITISH JOURNAL OF VENEREAL DISEASES}

The reason why I again take up this question for discussion is that $I$ wish to bring forward new material which may perhaps be of a certain interest.

Since and including the year I9I9 every case of syphilis in the infectious stage diagnosed by a physician has, under our Swedish "lex veneris," been compelled to undergo a prescribed treatment, and the patient can obtain this treatment free of charge at the expense of the State. The direct consequence of this has been that during the last seventeen years all cases of diagnosed syphilis in Sweden have been able to receive and usually also have received a vigorous specific treatment. Thus at St. Göran's Policlinic in Stockholm each case of fresh syphilis has been treated with at least 2 maximum combined series of $\mathrm{Hg}$ or $\mathrm{Bi}+$ salvarsan (each series of Io $\mathrm{Hg}$ or $\mathrm{Bi}+$ Io salvarsan of at least $6 \mathrm{gm}$. in all). Later the treatment has been continued for three years with about ten intermittent series of $\mathrm{Hg}$ or $\mathrm{Bi}$, each such series of ten injections. If clinical or serological recidivation were ascertained during treatment, more salvarsan was usually added. According to this method many, indeed probably most, syphilidologists in Sweden will have treated their syphilitic patients. Some, however, have adopted the method indicated by Almkvist with so-called continuous treatment of syphilis, a method which is based on large doses of $\mathrm{Hg}, \mathrm{Bi}$ and salvarsan (see Svensk Läkartidningen, I926).

Hence, theoretically it should already now be possible to see whether a vigorous specific treatment of syphilis acted in one direction or the other with respect to the appearance and frequency of late recurrences. We have learnt by experience, however, that it is very difficult to follow and subject to post-examination a large material of syphilis from the time of the infection onward through several decades. The patients will easily be lost sight of and when all are not found again, the result of the investigation will be of diminished value, it may indeed even be deceptive. Bruusgaard's above-mentioned investigation shows what the loss may be in these attempted inquiries. Of $2,18 \mathrm{I}$ cases of syphilis treated during the years I889-I9Io he was only able to obtain information about 25 per cent. ; of these 309 were alive and I64 deceased, i.e., a total of 473 .

Another method is to start from the late relapses and I78 


\section{PROGNOSIS OF SYPHILIS}

try to discover when these patients were infected, what treatment they have undergone, etc. In this case the difficulty lies mostly in procuring a large and wellobserved material, about which the desired information can be obtained with a fair degree of certainty. However, I consider that I am able to produce a fairly good material, in respect of late nervous symptoms, namely, the material from the Malaria Department of St. Göran's Hospital. During the years I927-34, 477 cases of late syphilitic cerebrospinal diseases have been under care there. Of these, however, the diagnosis has been doubtful in I6 cases. Hence they are not included in this account which therefore comprises $46 \mathrm{I}$ cases.

The material may perhaps be considered too small to warrant general conclusions. It is, however, practically as large as that of Bruusgaard. Lennmalm's investigation does not comprise nearly as many cases. For it is based on the death-rate statistics of the life insurance company Thule during the fifty-year period I873-I922. Syphilis is there given as the cause of death in 327 cases. Of 550 deceased insurees who were diagnosed as syphilitic on effecting the insurance, only 97 , or 17.63 per cent., had died of syphilitic infections

In Lennmalm's, as in other investigations based on life insurance, material first-hand information as to infection, diagnosis, treatment and the course of the disease is extremely scant, if present at all. As correctly pointed out by Rosenthal such statistic material, when large, may be of value in calculating average life-span and similar particulars, but for the estimation of the curability of syphilis it is without importance. As far as the material here to be discussed is concerned, the records of the cases are at any rate extremely accurate and full, and the diagnoses are based on detailed clinical observations with examination of the blood and cerebrospinal fluid in each case. The information in the records in respect of earlier treatment has, when necessary, been supplemented through written or oral inquiry of the physicians who have previously treated the patients. Thanks to their great helpfulness these particulars are now fairly complete. I am greatly indebted to Dr. Malcolm Tottie for his valuable help in collecting and coordinating this information. 


\section{BRITISH JOURNAL OF VENEREAL DISEASES}

The whole of the material has been divided into four sections according to the clinical diagnoses.
A. Syphilis cerebrospinalis - I32 cases.
B. Tabes dorsalis . • • 75 ",
C. Tabo-paralysis . . . 43 ",
D. Dementia paralytica. . 2II ",

$$
\text { Total . } \overline{46 I} \text {, }
$$

All these cases have then, according to the history given concerning treatment been again divided as follows :-

Group I.-Cases never treated before.

Group II.-Not treated until the late symptoms appeared.

Group III.-Cases treated insufficiently from the beginning.

Group IV.-Cases well treated from the beginning of the disease.

There was no difficulty in distinguishing Groups I. and II. With respect to Groups III. and IV. it should be noted that the designations " insufficiently " and " well" treated cases are quite subjective. In Group III. are included such cases as have only been subjected to short or irregular treatment with $\mathrm{Hg}$ or $\mathrm{Bi}$ alone, or perhaps one or two injections of salvarsan. In several cases the treatment was so deficient (e.g., " inunction with $\mathrm{Hg}$ for a month," " an Hg-bag cure," " some $\mathrm{Hg}$ injections ") that it can almost be regarded as if none had been given. This often applies to persons who have purposely avoided treatment, or owing to journeys have been unable to

\section{A. Syphilis Cerebrospinalis}

\begin{tabular}{|c|c|c|c|c|c|c|}
\hline & & \multirow{2}{*}{$\begin{array}{l}\text { Number } \\
\text { of cases. }\end{array}$} & \multirow{2}{*}{$\begin{array}{c}\text { Time of } \\
\text { infection } \\
\text { unknown. }\end{array}$} & \multicolumn{2}{|c|}{ Time of infection known. } & \multirow{2}{*}{$\begin{array}{c}\text { Latent } \\
\text { periorl of } \\
\text { late } \\
\text { symptoms. } \\
\text { Years. }\end{array}$} \\
\hline & & & & $\begin{array}{l}\text { Number } \\
\text { of cases. }\end{array}$ & $\begin{array}{l}\text { Per cent. } \\
\text { of group. }\end{array}$ & \\
\hline \multirow[t]{2}{*}{$\begin{array}{l}\text { Group I. } \\
\text { Group II. } \\
\text { Group III. } \\
\text { Group IV. }\end{array}$} & - & $\begin{array}{l}21 \\
53 \\
45 \\
13\end{array}$ & $\begin{array}{r}\text { I8 } \\
50 \\
0 \\
0\end{array}$ & $\begin{array}{r}3 \\
3 \\
45 \\
13\end{array}$ & $\begin{array}{r}14 \cdot 3 \\
5 \cdot 7 \\
\text { I00 } \\
\text { I00 }\end{array}$ & $\begin{array}{r}\text { I6.7 } \\
8 \cdot 7 \\
17 \cdot 0 \\
\text { I0・0 }\end{array}$ \\
\hline & & I32 & 68 & 64 & $48 \cdot 5$ & I3.I \\
\hline
\end{tabular}




\section{PROGNOSIS OF SYPHILIS}

\section{B. Tabes Dorsalis}

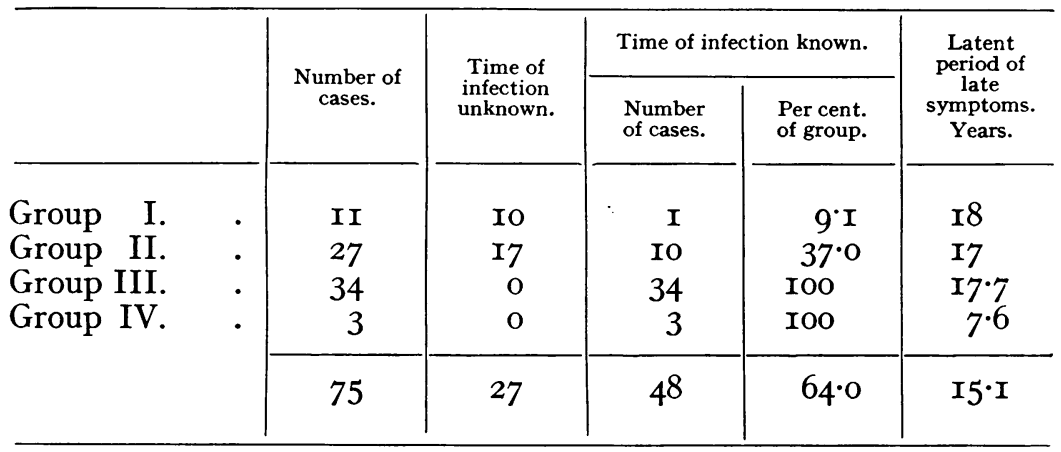

C. TABO-PARALYSis

\begin{tabular}{|c|c|c|c|c|c|c|}
\hline & \multirow{2}{*}{$\begin{array}{l}\text { Number } \\
\text { of cases. }\end{array}$} & \multirow{2}{*}{$\begin{array}{l}\text { Time of } \\
\text { infection } \\
\text { unknown. }\end{array}$} & \multicolumn{2}{|c|}{ Time of infection known. } & \multirow{2}{*}{$\begin{array}{c}\text { Latent } \\
\text { period of } \\
\text { late } \\
\text { symptoms. } \\
\text { Years. }\end{array}$} \\
\hline & & & & $\begin{array}{l}\text { Number } \\
\text { of cases. }\end{array}$ & $\begin{array}{l}\text { Per cent. } \\
\text { of group. }\end{array}$ & \\
\hline \multirow{5}{*}{$\begin{array}{ll}\text { Group } & \text { I. } \\
\text { Group } & \text { II. } \\
\text { Group } & \text { III. } \\
\text { Group } & \text { IV. }\end{array}$} & • & 9 & 8 & I & $I I \cdot I$ & I 8 \\
\hline & . & 12 & Io & 2 & I6.7 & II $\cdot 5$ \\
\hline & - & $2 I$ & 0 & $2 \mathrm{I}$ & roo & $I 8 \cdot I$ \\
\hline & • & I & o & I & IOO & I 2 \\
\hline & & 43 & I8 & 25 & $58 \cdot I$ & I $4 \cdot 9$ \\
\hline
\end{tabular}

D. Dementia Paralytica

\begin{tabular}{|c|c|c|c|c|c|}
\hline & \multirow{2}{*}{$\begin{array}{l}\text { Number } \\
\text { of cases. }\end{array}$} & \multirow{2}{*}{$\begin{array}{c}\text { Time of } \\
\text { infection } \\
\text { unknown. }\end{array}$} & \multicolumn{2}{|c|}{ Time of infection known. } & \multirow{2}{*}{$\begin{array}{c}\text { Latent } \\
\text { period of } \\
\text { late } \\
\text { symptoms. } \\
\text { Years. }\end{array}$} \\
\hline & & & $\begin{array}{l}\text { Number } \\
\text { of cases. }\end{array}$ & $\begin{array}{l}\text { Per cent. } \\
\text { of group. }\end{array}$ & \\
\hline Group I. & 64 & 59 & 5 & $7 \cdot 8$ & $\mathrm{I} 3 \cdot 8$ \\
\hline Group II. & 60 & 50 & IO & $16 \cdot 7$ & $\mathrm{I} 4 \cdot 3$ \\
\hline Group III. & 85 & 0 & 85 & IOO & $16 \cdot 2$ \\
\hline \multirow[t]{2}{*}{ Group IV. } & 2 & o & 2 & IOO & 13.5 \\
\hline & $2 \mathrm{II}$ & Iog & I02 & $48 \cdot 3$ & $\mathrm{I} 4 \cdot 4$ \\
\hline
\end{tabular}

carry it through. Group III. also includes some older cases, where the infection and treatment date from the time of and before the enactment of the law in Igrg. With respect to Group IV. a summary will be given in the sequel including information as to treatment. First we will, however, take a look at the different sections (A, $\mathrm{B}, \mathrm{C}$ and $\mathrm{D})$. 
Starting from these tables we will first consider whether the treatment may have any bearing on the onset of late syphilitic nervous symptoms. Groups I. and II. will be taken together here since no specific therapy was applied to the cases of Group II. until the nervous symptoms had already been diagnosed.

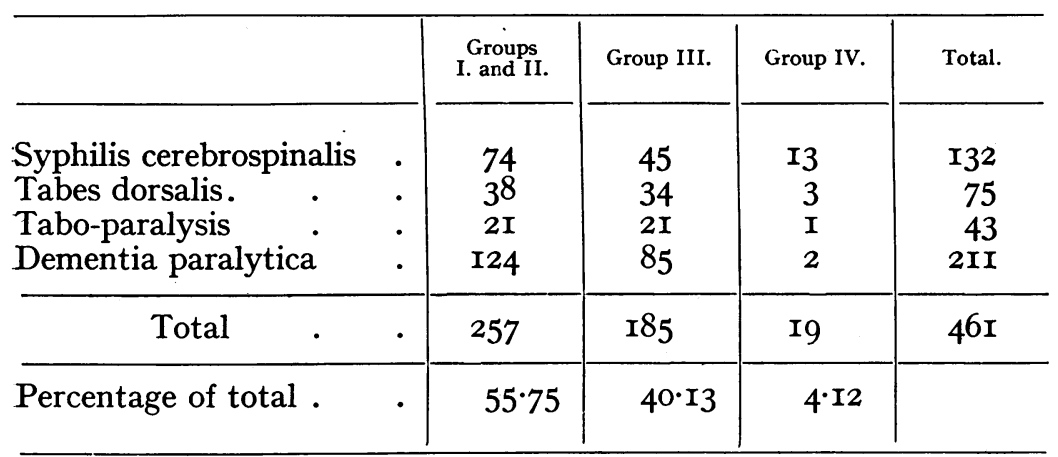

That the infection of more than half of all the individuals who contracted syphilis in Sweden during the last decades should have remained undiscovered until late nervous symptoms appeared, and that only about 4 per cent. of the cases with recent syphilis during the same period of time should have obtained thorough treatment is not likely. There is the very greatest probability that this is far from being the case. In our aforementioned lex veneris the tracing of the sources of infection enters as an important element in the fight against the venereal diseases. This contributes to the discovery of more cases of syphilis than before, hence it can safely be asserted that the cases of syphilis ignota have now in Sweden been reduced as far as is possible. Probably the number of undiscovered early cases of syphilis is considerably lower than that of the cases of early syphilis treated lege artis. Under these circumstances the investigation shows that the specific treatment has not here provoked nervous symptoms but on the contrary has been capable of preventing such.

Out of 46I cases of syphilis in the central nervous system only $4 . \mathrm{I} 2$ per cent. have undergone vigorous treatment from the beginning of the infection. If we consider alone cases of the so-called syphilis parenchyI 82 


\section{PROGNOSIS OF SYPHILIS}

matosa (tabes, tabo-paralysis, dementia paralytica), which, incidentally, are generally the least susceptible to the usual anti-syphilitic treatment and where the prognosis is as a rule less favourable than in syphilis cerebrospinalis, these constitute 329 cases. Of these only 6 , or $\mathrm{I} \cdot 63$ per cent. have been well treated from the beginning.

The predominant number of cases in Group I., however, are syphilis cerebrospinalis. This diagnosis comprises a particularly variable facies morbi with a medley of symptoms. Sometimes they are mild and easily overlooked, in other cases they set in suddenly, become very severe and quickly lead to death. Between these extremes there occur countless variations. Cerebrospinal syphilis sets in at different times, thus occasionally during the secondary stage, already some months after infection, but also much later, at any period of life. Even though basal meningites are perhaps more often seen during the secondary stage than later during the tertiary stage, an oft-quoted old pronouncement by Mauriac as to the facies morbi of cerebrospinal syphilis still applies: “ qu'elles sont precoces ou tardives, qu'elles appartiennent à la phase secondaire, ils ont toujours la même physionomie generales et la même gravité."

On examining the case histories in Group IV. one is struck by the fact that instances are there often met with in which the infection, despite the most thorough treatment with salvarsan, $\mathrm{Bi}$ and $\mathrm{Hg}$, has progressed and developed into a neurosyphilis. It would almost seem as if a number of cases were predestined for this, and the cause of this malignity is extremely enigmatical. In order, if possible, to reduce the number of such cases and further to cut short their progress we must not weary in our care where the treatment and observation of the patients is concerned. The examination of the cerebrospinal fluid is especially an important aid in checking the results of treatment. If these do not seem satisfactory in some respect or other, if, e.g., there is stubborn positive W.R. in blood, changes of the cerebrospinal fluid, vague nervous symptoms, etc., there should be no delay in instituting a malaria treatment. Unfortunately it is seen only too often that such a treatment is begun so late, that in the most favourable cases it can only bring about a defective healing. 


\section{BRITISH JOURNAL OF VENEREAL DISEASES}

Brief History of the Cases in Group IV.

Case I.-A woman, born in I897. Infected with syphilis in I9I4 and treated by Dr. K. Marcus. Received regular treatment with salvarsan and $\mathrm{Hg}$ for three years. Not seen later until I926. Was then admitted to the Malaria Department.

Diagnosis : syphilis cerebrospinalis.

Case 2.-A woman. Born in I892. Infected with syphilis in I9I9. Remains of sclerosis + mucous papules. W.R. positive. Treated later by Professor Almkvist.

I9I9: 9 salvarsan $+39 \mathrm{Hg}$.

\begin{tabular}{|c|c|c|}
\hline & & of year. \\
\hline Ig2I : & & $\begin{array}{l}\text { I8 } \mathrm{Hg} ; \mathrm{W} . \mathrm{R} \text {. positive at beginnin } \\
\text { of year. }\end{array}$ \\
\hline I922: & & $\begin{array}{l}20 \mathrm{Hg} \text {; W.R. positive at beginnin } \\
\text { of year. }\end{array}$ \\
\hline I923: I0 & & + Io $\mathrm{Hg}$ \\
\hline I924: IO & , & + ro $\mathrm{Hg}$ \\
\hline I925: I5 Bi & & $\begin{array}{l}+ \text { Io } \mathrm{Hg} ; \text { W.R. negative at beginni } \\
\text { of year. }\end{array}$ \\
\hline
\end{tabular}

I926 : $40 \mathrm{Bi}$.

I927: $39 \mathrm{Bi}$. Admitted to the Malaria Department.

Diagnosis : syphilis cerebrospinalis.

Case 3.-A man, born in 1898 . Infected with syphilis in I928. Extensive roseola. Treated regularly for years with salvarsan $+\mathrm{Hg}$. In I924 W.R. was found to be positive, was given $20 \mathrm{Bi}$. I925 W.R. still positive, was given Io salvarsan. In the autumn of 1926 continuous treatment started with salvarsan $+\mathrm{Hg}+\mathrm{Bi}$ according to Almkvist. This treatment was terminated at the beginning of the year I927. W.R. was then still positive. In November of the same year some nervous symptoms set in, general restlessness, etc. Gradually became subject to fits of vertigo and dizziness. Transient unconsciousness. Was admitted to the Malaria Department. Diagnosis : syphilis cerebrospinalis.

Case 4.-A man, born in I9oo. Infected with syphilis in I923. Sclerosis, W.R. positive. Twelve treatments with salvarsan and $\mathrm{Hg}$, the last treatment terminated in November, I927. W.R. taken five times during treatment, always negative, the last time in November, I927. 


\section{PROGNOSIS OF SYPHILIS}

In February, I928, acute retention of the urine. Saw a physician about it : urine collected. Continued difficulty in urination. Admitted to the Malaria Department. Diagnosis : syphilis cerebrospinalis.

Case 5.-A man, born in $\mathrm{I} 88 \mathrm{r}$. Infected with syphilis in I9I4. Continuous treatment by Dr. Marcus with salvarsan and $\mathrm{Hg}$. Last treatment in I926. W.R. was then positive. Admitted to the Malaria Department in I928. Diagnosis : syphilis cerebrospinalis.

Case 6.-A man, born in I892. Infected with syphilis in I9I9. I9I9-2I under the care of Dr. S. Birger in Stockholm. Repeated treatments of salvarsan and $\mathrm{Hg}$. Moved to the provinces and continued there with salvarsan $+\mathrm{Hg}+\mathrm{Bi}$ during the years I92I-29. As W.R. remained positive he was admitted to the Malaria Department. Diagnosis : syphilis cerebrospinalis.

Case 7.-A man, born in I889. Infected with syphilis in I9I9. Sclerosis + roseola + W.R. positive. $\mathrm{He}$ received, till the end of November, I922, 9 treatments with $\mathrm{Hg}$ in conjunction with salvarsan, altogether 32 injections usually of $0.9 \mathrm{~g}$. salvarsan sodium (ns).

I923 : April W.R. indistinct.

May W.R. positive. Six salvarsan ( 5 g. ns).

I924: January W.R. faintly positive, treatment with $\mathrm{Bi}+3 \cdot \mathrm{I} 5 \mathrm{~g} . \mathrm{ns}$.

March W.R. negative.

I926: April W.R. positive, vague nervous symptoms, "creepy all over." Treatment with $\mathrm{Bi}+5 \cdot 4$ g. ns.

June W.R. positive. Treatment with $\mathrm{Bi}+6 \cdot 3$ g. ns.

Autumn W.R. negative.

I927 : Spring W.R. negative.

September W.R. faintly positive, fresh treatment after which W.R. was negative.

I929: W.R. negative, since the summer constantly sluggish pupils. September W.R. positive in the cerebrospinal fluid. Treatment with $\mathrm{Bi}+$ Io ns $(8 \cdot 25$ g.).

I930 : January W.R. negative. Endolumbar injection 0.5 mg. ns. Admitted to the Malaria Department. Diagnosis : syphilis cerebrospinalis.

Case 8.-A man, born in 1873. Infected with syphilis v.s. I 85 
in I925. Secundaria, W.R. positive. Treated until the beginning of $\mathrm{I} 928$ with Io salvarsan +7 series of $\mathrm{Hg}+\mathrm{I}$ series of $\mathrm{Bi}$. In I928 further 4 salvarsan. In I929 pain in the loins, tired and sometimes dizzy. The symptoms increased, and since W.R. was positive, he was admitted to the Malaria Department in I93I. Diagnosis : syphilis cerebrospinalis.

Case 9.-A man, born in 1898 . Infected with syphilis in I929. Primary sclerosis + W.R. positive. Two maximum series of salvarsan + Bi. W.R. I930 negative. In 1932 he was admitted to the Malaria Department. Diagnosis : syphilis cerebrospinalis.

Case I0.-A man, born in 1877 . Infected with syphilis in I9I7. Sclerosis + roseola. Treatment for three years with a total of $\mathrm{I} 2 \mathrm{Hg}$ series, in addition 2 salvarsan in each series. In I920, following immediately upon discontinuance of treatment, bilateral " trigeminus paralysis." Saw Professor Nonne at Hamburg, who performed a lumbar puncture. " A very little lues." Advised against salvarsan, prescribed inunctions, which advice the patient followed. In I922 a physician diagnosed psoriasis plantaris. The patient was given $\mathrm{Bi}$ for three years until I925. After I928 various nervous symptoms : loss of taste, change of disposition, numbness of legs. In I930 lumbar puncture, " some bad tests," amongst others W.R. in the cerebrospinal fluid positive. The nervous symptoms increased and the patient was admitted to the Malaria Department in I93I. The W.R. of the blood was never positive (not taken at the beginning of the first treatment in I9I7). Diagnosis: syphilis cerebrospinalis.

Case II.-A man, born in 1893 . Infected with syphilis in Chile in I926. Had then a distinct exanthema. Was at once given $2 \mathrm{Hg}$ treatments (number of injections?). W.R. being strongly positive treatment with salvarsan and $\mathrm{Bi}$ was continued until I93I. Lumbar puncture at Berne in I93I with negative findings. W.R. in blood then negative for two years. Admitted to the Malaria Department in I932. Diagnosis : syphilis cerebrospinalis.

Case I2.-A woman, born in Igoo. Infected with syphilis I9I9. Sclerosis + extensive secundaria. Treated till I923 with a total of 25 salvarsan + IO3 $\mathrm{Hg}+\mathrm{I} 4 \mathrm{Bi}$. W.R. throughout positive. Stopped treatment and warnings had no effect. Treatment resumed in 1926 I 86 


\section{PROGNOSIS OF SYPHILIS}

and since continued till September, I928. During this period she received a total of 98 salvarsan + II2 $\mathrm{Bi}$ + Io Hg. Admitted to the Malaria Department in September, I928. Diagnosis : syphilis cerebrospinalis.

Case I3.-A man, born in 1898 . Infected with syphilis in Hamburg in I92I. Was there given 5 salvarsan and $8 \mathrm{Hg}$ injections. Some months later in Stockholm 5 salvarsan $+7 \mathrm{Hg}$ injections. In April, I922, epileptiform fits. Lumbar puncture: W.R. negative, great . increase of cells, 220 cells per cubic millimetre. W.R. in blood negative. As the patient contracted a severe stomatitis and evidently tolerated $\mathrm{Hg}$ badly, treatment was continued with salvarsan and Ki only. In April, altogether 6 salvarsan (of which 5 silver salvarsan). On October Ist, I922, suddenly severe epileptiform fits (status epilepticus).- Salvarsan + Ki. In I923, 7 salvarsan. Later the patient kept away and did not come back for treatment until April, I928, when he complained of headache and giddiness. W.R. positive (stated that tests had been taken with negative result twice in the interval). Was now given 9 salvarsan and was subjectively well. Admitted to the Malaria Department in I932. Diagnosis : syphilis cerebrospinalis. At times there appeared to have been excessive indulgence in alcohol.

Case I4.-A man, born in I889. Infected with syphilis in I9I6. Repeated treatment with salvarsan and $\mathrm{Hg}$ for three years. W.R. negative in I9I8. In I920 cerebral hæmorrhage. W.R. strongly positive, paralysis of left leg. Regressed during treatment for seven to eight months. Until and in I92I abundant salvarsan and $\mathrm{Hg}$. After this repeated treatments, the last few years with $\mathrm{Bi}$, until March, I928. W.R. in cerebrospinal fluid then positive. The patient had a psychic breakdown and became irritable and violent. After 1923, occasionally shooting pains in the extremities. Admitted to the Malaria Department in I928. Diagnosis : Tabes dorsalis.

Case I5.-A man, born in I888. Infected with syphilis in I9II. Sclerosis of the lips. According to information received from Professor Antoni, the patient had undergone abundant treatment from the beginning, first with salvarsan in series, later intermittently with much $\mathrm{Hg}$ and $\mathrm{Bi}$ until I930, when he was admitted to the Malaria Department. Diagnosis : tabes dorsalis. 


\section{BRITISH JOURNAL OF VENEREAL DISEASES}

Case I6.-A man, born in I9oo. Infected with syphilis in I9I8 or I9I9. First treated at the Holterman Hospital at Göteborg and later continued with regular treatment at the policlinic of the hospital for three years. Repeated blood samples taken later on were always negative. In I93I sudden neuralgic pain and lancinating pains in the legs. Admitted to the Malaria Department. Diagnosis : tabes dorsalis.

Case I7.-A man, born in I897. Infected with syphilis in I920. Sclerosis + sclerotic adenitis. Treatment instituted at once and continued for four years. Every year 15 salvarsan and 2 to 3 series of $\mathrm{Hg}$ or $\mathrm{Bi}$ of 7 injections each, i.e., in all 60 salvarsan and about $60 \mathrm{Hg}$ or $\mathrm{Bi}$ injections. Annual blood samples negative until I93I, when the reaction became positive. Was then given salvarsan $+\mathrm{Hg}$ continually for a year. Admitted to the Malaria Department in I922. Diagnosis: taboparalysis + ethylismus chronicus.

Case I8.-A man, born in $\mathrm{I} 88 \mathrm{I}$. Syphilis recens in I9I2. Treated immediately with $\mathrm{Hg}$ and salvarsan, Io treatments in each series. Treatment continued at short intervals for four years. During the years I926-33 periodical $\mathrm{Bi}$-series. Thus the patient has received much salvarsan as well as $\mathrm{Hg}$ and $\mathrm{Bi}$. It has not been possible to ascertain the exact number of injections. Admitted to the Malaria Department. Diagnosis: Dementia paralytica.

Case I9.-A woman, born in 1894. Abortion in the fifth month of I9I6. Had then a "blister" in the vulva. W.R. strongly positive. Went to the policlinic in I927. Remains of papules in vulva. W.R. strongly positive.

I927 : ro salvarsan + Io $\mathrm{Bi}$.

I928: I8 , $\quad+29 \mathrm{Bi}$.

I929: Io $\mathrm{Bi}$.

I930 : ro , $\quad+$ Io $\mathrm{Bi}$.

I932: 7 ", + ro $\mathrm{Bi}$.

W.R. was negative at the test in I929, the other years positive. The patient evaded treatment in I93I. Towards the close of 1933 she began to stutter and showed a peculiar behaviour. Admitted to the Malaria Department in I934. Diagnosis : dementia paralytica.

It has been pointed out as a disadvantage attaching to the treatment in respect of the outset of neurosyphilis, 


\section{PROGNOSIS OF SYPHILIS}

that the latent period between the infection and the neuro-recidivation is shorter in treated than in untreated cases. Let us see how matters stand in our material.

According to the case histories the latent period was :-

Unknown in . 222 cases, i.e., in $48 \cdot 2$ per cent. Known in . 239 cases, i.e., in $5 \mathrm{I} \cdot 8$ per cent.

Total . 46I cases

The length of the latent period in the different groups will appear from the table below.

\begin{tabular}{|c|c|c|c|c|c|c|}
\hline & & $\begin{array}{l}\text { Number of } \\
\text { cases. }\end{array}$ & $\begin{array}{l}\text { Per cent. } \\
\text { of all cases. }\end{array}$ & $\begin{array}{c}\text { Cases with } \\
\text { known latent } \\
\text { period. }\end{array}$ & $\begin{array}{l}\text { Per cent. of } \\
\text { each group. }\end{array}$ & $\begin{array}{c}\text { Averaze } \\
\text { latent period. }\end{array}$ \\
\hline \multirow{3}{*}{$\begin{array}{lr}\text { Group } & \text { I. } \\
\text { Group } & \text { II. }\end{array}$} & \multirow{3}{*}{. } & ro5 & $22 \cdot 8$ & IO & 9.5 & $\begin{array}{l}\text { Years. } \\
16 \cdot 6\end{array}$ \\
\hline & & I58 & $33^{\circ} 0$ & 35 & $23 \cdot 0$ & $12 \cdot 9$ \\
\hline & & 257 & $55^{\cdot} 8$ & 45 & $\mathrm{I} 7 \cdot 5$ & I $4 \cdot 75$ \\
\hline \multirow{2}{*}{$\begin{array}{l}\text { Group III. } \\
\text { Group IV. }\end{array}$} & . & I 85 & $40 \cdot I$ & I 85 & 100 & $17 \cdot 3$ \\
\hline & . & I9 & $4 \cdot I$ & I9 & IOO & $10 \cdot 8$ \\
\hline
\end{tabular}

This table, then, shows that

45 cases not treated from the beginning have a latent period of 14.75 years.

I85 cases treated from the beginning, but insufficiently, have a latent period of $\mathrm{I} 7 \cdot 3$ years.

I9 cases well treated from the beginning have a latent period of $10 \cdot 8$ years.

If these figures are accepted unconditionally, the result will be highly peculiar. The outlook would be worst for the well-treated patients (shortest latent period), considerably better for untreated patients, and best of all for insufficiently treated patients.

Here it should be pointed out that the latent period is only known for half the number of cases, for which reason the figures are very low. We cannot exclude the possibility that the result would be quite different if the latent period were known in every case. There are particularly few well-treated cases in our material. Furthermore, it is difficult to fix a time for the onset of the late relapses especially, as is often the case, when 
they are insidious. Therefore, the latent period is not infrequently calculated more or less approximately. In Case 7, for example, where the patient was infected in I9I9, a number of vague nervous symptoms appeared as early as I926, which, however, disappeared after continued treatment with salvarsan and $\mathrm{Bi}$. Not until I930 was this case diagnosed as syphilis cerebrospinalis. Had repeated spinal punctures been performed during the treatment, this diagnosis would probably have been made much earlier. That the latent period is often given as being longer in untreated than in well-treated cases may be explained to a certain degree by the fact that the latter are usually under careful control and the symptoms observed earlier than in the untreated cases who do not see a doctor until the symptoms are more pronounced. Hence the value of the information regarding the latent periods and their relation to the treatment is very problematic. The literature contains many contradictory reports on this question. Unfortunately, it cannot be denied that there are cases which do not react satisfactorily despite consistent and intensive treatment with salvarsan and $\mathrm{Bi}$ or $\mathrm{Hg}$ shortly after infection. Still, in our material, their number seems to be relatively small. However, late symptoms and a short latent period between the infection and recidivation should not be unconditionally interpreted as a direct result of the treatment, as this relationship has not been proved.

The result of this investigation must not be too generalised. The material is too scant and, furthermore, we have only taken into consideration the late symptoms in the nervous system. So much may, however, be said that it has lent support to an optimistic view of the value of the treatment, even when the object is to prevent the gravest consequences of the disease.

Nihilism and distrust must not discourage us ; on the contrary, each advance should incite us to further efforts in our endeavour to improve the prognosis of syphilis.

\section{Discussion}

BoAs said that of 35 cases of dementia paralytica from the Frederiksberg Hospital only one was really well treated.

Lomholt : Dr. Strandberg's investigation must be 190 


\section{PROGNOSIS OF SYPHILIS}

welcomed with gratitude. As far as I know, it is the first time such a collective view has been presented, and fortunately it has given a clear, positive answer. Cases of syphilis which have been well treated from the beginning are only to a very slight degree threatened with the danger of late outbreaks in the central nervous system. This closes a long-lasting, very confusing discussion, and all talk of the risk of diverting the natural course of the syphilitic infection by suddenly stopping it must now come to an end.

Only a couple of practical questions at last. How and where is the limit drawn between well-treated and insufficiently treated cases?

What indications are given for the institution of a malaria treatment? I have for many years as far as possible followed the rule of giving malaria to all syphilitic patients who when spinal puncture is performed, usually a year after the termination of the current treatment, show a distinct pleocytosis (> I4/3), and with very encouraging results.

STRANDBERG (in reply): In reply to Dr. Lomholt's first question I should like to say that of course there are a number of cases in which it has been difficult to decide whether the treatment has been "insufficient" or " good," that is to say, whether they should be placed in Group III. or IV. When the patients had had a fairly regular three-yearly treatment, even though the salvarsan treatment had been deficient, they were placed in Group IV. The treatment given to the well-treated cases in which nerve symptoms developed will appear from the case histories.

My reply to the second question is, that at St. Göran's Hospital we have been very liberal with malaria treatment. We have been anxious to get neurosyphilis under malaria treatment as early as possible. Even cases exhibiting no symptoms of neurosyphilis, but in which other symptoms, for instance, obstinate positive W.R. in the blood, seemed to indicate that the current treatment had not been satisfactory, were as far as possible treated with malaria. 